\title{
Financing Social Protection
}

\section{Armando Barrientos}

October 2007

Brooks World Poverty Institute

BWPI Working Paper 5

Armando.Barrientos@manchester.ac.uk

Brooks World Poverty Institute, School of Environment and Development, Humanities Bridgeford Street, University of Manchester, Oxford Rd, Manchester, M13 9PL 


\begin{abstract}
There has been much discussion and debate on the kind of institutions and policies that could best address poverty and vulnerability in developing countries. Financing has emerged as a key constraint on the extension of social protection. The paper considers the main sources, and key constraints, of the financing mix for social protection in developing countries, and especially low income countries among them. It argues that achieving an appropriate financing mix is essential to ensure the resources required are available. It is also important in strengthening the incentives for poverty and vulnerability reduction, and in reinforcing the legitimacy of social protection institutions and programmes.
\end{abstract}

Keywords: social protection, vulnerability, financing, insurance, savings

Dr Armando Barrientos joined BWPI as Senior Research Fellow in August 2007. He was formerly a Research Fellow at Institute of Development Studies, University of Sussex, and Senior Lecturer at Institute for Development Policy and Management at the University of Manchester. Armando is also a Senior Researcher with the Chronic Poverty Research Centre, leading research on the Insecurity, Risk and Vulnerability research theme. His research interests focus on the linkages existing between social protection and labour markets in developing countries, and policies addressing poverty, vulnerability, and population ageing. 


\section{Introduction}

There is a consensus emerging among international organisations and national governments in developing countries that social protection provides an effective policy framework for addressing rising poverty and vulnerability in the global economy. Social protection can be defined as all interventions from public, private, voluntary organisations and informal networks, to support communities, households and individuals, in their efforts to prevent, manage, and overcome a defined set of risks and vulnerabilities. Social protection is an extension of anti-poverty policy. It is grounded in the view that vulnerability, understood as the limited capacity of some communities and households to protect themselves against contingencies threatening their living standards, is a primary factor explaining poverty. It is also a key factor explaining the low levels of human capital investment observed among households in poverty, which prevent them from taking advantage of economic and social opportunities.

In line with this emerging consensus, many national governments and international organisations are taking steps to establish and strengthen social protection institutions and policies. In the context of middle income countries, these efforts involve the strengthening of existing institutions and policies, and a renewed focus on poverty and vulnerability. This is very much in evidence among Latin American countries that have recently introduced income transfer programmes focused on strengthening consumption and human capital investment by the poor and poorest (Morley and Coady 2003; Barrientos and Holmes 2006). In low income countries, social protection institutions and policies are scarce, and the main emphasis is on establishing these anew. This applies especially to countries in Sub-Saharan Africa (Commission for Africa 2005).

There has been much discussion and debate on the kind of institutions and policies that could best address poverty and vulnerability, and considerable activity and innovation on the ground. In these discussions, financing has emerged as a key constraint on the development of social protection. There are different sources of financing for social protection. These include aid from international donors, revenues of national governments, private, community, and NGO financing, and household saving and out of pocket expenditures. The problem is to set in place an effective and sustainable financing mix for social protection institutions and policies (ILO 2001; Holzmann, Sherbourne-Benz et al. 2003). This is a complex problem, in that the issues involved are as much to do with economics as with politics and the background is one of rapid social and economic transformation. ${ }^{1}$ An optimal financing mix is essential to (i) generating the resources needed to establish and strengthen appropriate social protection systems; (ii) ensuring the incentives generated by the financing modalities reinforce poverty and vulnerability reduction; and (iii) securing legitimacy for social protection institutions and policies.

The main purpose of this chapter is to consider the nature and constraints of the financing mix for social protection in developing countries, and especially low income countries among them. The paper is divided into four sections. The next section provides a brief and informal discussion of the main elements of the financing mix, and their linkages. The following two sections focus on two key components of this mix: national government's and international organisations' funding for social protection. The last section reviews the key issues ahead and concludes.

\footnotetext{
${ }^{1}$ In low income countries, for example, donors had been traditionally resistant to engage with longterm social protection programmes, such as old age pensions or child benefits, on the grounds that these countries would not be able to finance these programmes in the medium run. Changes in the pattern of vulnerabilities, e.g. those brought about by the incidence of HIVIAIDS and migration, and in the focus of development organisations and national governments on poverty reduction, are helping develop partnerships for long term social protection.
} 


\section{The financing mix for social protection}

As indicated above, the sources of finance for social protection are many and the focus should be on the financing mix. The dynamics of this mix has a direct relationship to economic development. Comparative data on the financing of health care provides us with an insight into the differences in the financing mix across regions and the dynamics associated with development. Summary information is presented in Table 16.1 below. $^{2}$ The figures in the Table show the differences in the financing mix across the different regions. The share of health expenditures financed by government revenues is dominant in the OECD region, but less so as we move to less developed regions. Another key difference is the large share of social insurance financing in the developed nations, especially when compared to lower income regions. Among less developed regions, out of pocket financing is substantial, and external sources of finance are important in SSA and Asia.

Table 16.1: Regional comparison of health services financing mix 2002 (\% of total health expenditure)

\begin{tabular}{lllllll}
\hline & \multicolumn{3}{c}{ Public } & \multicolumn{3}{c}{ Private } \\
& $\begin{array}{l}\text { Revenue } \\
\text { financed }\end{array}$ & $\begin{array}{l}\text { Externally } \\
\text { financed }\end{array}$ & $\begin{array}{l}\text { Social } \\
\text { insurance }\end{array}$ & $\begin{array}{l}\text { Pre-paid } \\
\text { plans }\end{array}$ & $\begin{array}{l}\text { NGO/ } \\
\text { Occupational }\end{array}$ & $\begin{array}{l}\text { Out of } \\
\text { pocket }\end{array}$ \\
\hline OECD & 47.2 & 0 & 25.3 & 7.1 & 2.1 & 18.3 \\
$\begin{array}{l}\text { Latin America } \\
\text { and the }\end{array}$ & 38.8 & 3.9 & 13.8 & 6 & 2.8 & 34.7 \\
$\begin{array}{l}\text { Caribbean } \\
\text { South Asia }\end{array}$ & 37.6 & 10.1 & 1.4 & 0 & 1.5 & 49.4 \\
$\begin{array}{l}\text { Sub-Saharan } \\
\text { Africa }\end{array}$ & 40.7 & 16.4 & 0.1 & 2.8 & 4.6 & 35.4 \\
\hline
\end{tabular}

Source: Own calculations using country data from The World Health Report 2002 (World Health Organization 2003), classified according to regional classification from the World Bank website. The residual in public expenditure is general government expenditure. The residual in private expenditure is NGOs and occupational plans financed health expenditure.

The dynamics implicit in the figures in the Table apply fully to social protection. In OECD countries, social protection is primarily financed through tax revenues and social insurance contributions. Broadly, the task ahead for low income developing countries is to reduce the share of out of pocket financing and raise the share of government revenue financing and, perhaps in the short run, external financing too. The changes in the financing mix need to take place in the context of an increase in the overall volume of resources available for social protection. In middle income developing countries, the role of social insurance financing also needs to be considered. ${ }^{3}$

While setting out the task ahead appears to be relatively straightforward, outlining a road map is a difficult undertaking. As noted above, an appropriate financing mix needs to raise the required resources for social protection, but also ensure that at the same time the

\footnotetext{
${ }^{2}$ Comparative and reliable data on social protection expenditure is sorely lacking. Recent changes to the IMF's guidelines on the reporting of public expenditure on social protection will facilitate comparative analysis in the future, but estimates of out-of-pocket household expenditure on social protection are scarce.

${ }^{3}$ It is debatable whether increasing the share of social insurance financing is realistic even for middle income countries, especially as the share of social insurance financing is in decline among OECD countries. This important issue will not be discussed further below, as our focus is on low income countries.
} 
incentives for poverty and vulnerability reduction are strengthened, and the legitimacy of social protection institutions is reinforced. Microeconomic and political economy perspectives on the financing mix for social protection provide essential road signs for developing income countries. Space restrictions mean that only the briefest of outlines is possible here.

How do households respond to contingencies which may threaten their living standards? Gill reviews and updates a simple model of households' demand for insurance developed originally by Ehrlich and Becker (Ehrlich and Becker 1972; Gill and Ilahi 2002), which helps pinpoint three main strategies. Households could take steps to reduce the likelihood that the contingencies may occur. For example, investment in health care checks, nutrition, and schooling will improve their human capital and reduce the likelihood of unemployment or low wages. Alternatively, households could focus on reducing the losses which may result, in the event that the contingencies materialise. There are, broadly, two strategies which ameliorate these losses. Households may protect themselves by accumulating assets or entitlements which could compensate them in the event of losses. They could save some of their income to survive periods of unemployment. A third strategy would be to join an insurance scheme covering households threatened by similar contingency, in which a small premium will ensure a measure of compensation for the associated losses, as in unemployment insurance schemes. The three main strategies are: self-protection, saving, and insurance.

The insights provided by the model into the way households respond to contingencies have important implications for the financing mix for social protection. Firstly, households are better off if they are able to use the full range of options: self-protection, saving and insurance. Extending the range of available social protection instruments meeting households demand should facilitate household financing as well as improve their protection. Secondly, insurance solutions are more effective for large-losses-low-frequency contingencies, while saving solutions are more effective for small losses-high frequency contingencies. This implies that community or trade insurance schemes may have limited scope, and therefore constitute a limited source of financing for social protection. Microsaving schemes, on the other hand, are a potentially important source of finance in low income countries. Unfortunately, in many developing countries micro-finance institutions make savings compulsory and discourage easy access to withdrawals. As a result, many of these schemes provide only limited social protection.

Thirdly, trade-offs between the different strategies also have implications for the financing mix. Saving and insurance are substitutes, with the implication that improving the availability of insurance will reduce precautionary saving. Compulsory insurance may be sub-optimal if it 'crowds out' optimal levels of precautionary saving, and especially so if it packages in a mix of desirable and undesirable insurance. Self-protection, on the other hand, can be complementary to saving and insurance, with the implication that improving the provision of insurance, public or private, may not necessarily involve a reduction in households' selfprotection efforts, a concern commonly expressed by policy makers.

There is much less clarity on the insights from political economy models for the financing of social protection. Public choice models suggest that self-interested tax payers would be more inclined to finance social protection if it benefits them directly (Gelbach and Pritchett 1995), or if the indirect benefits, say from a reduction in social unrest or crime, are large. However, these models would also be consistent with tax payers seeking to 'truncate' social protection institutions, as in Latin America, or invest in law and order instead. Public understanding and values, on the causes of poverty and vulnerability, and the effectiveness of potential remedies, are also important in generating support for financing social protection institutions and programmes. In the context of external financing for social protection, the latter are significant in persuading tax payers in different jurisdictions to finance social protection in developing countries. Political economy factors are important in explaining public financing of social protection. This goes some way to explaining regional and sub-regional differences in the evolution of social protection institutions. In Southern Africa, cash transfers are the main 
policy instrument, whereas other Sub-Saharan countries favour in-kind transfers (See the papers by Hickey and Ngozi in this volume).

A less precise but perhaps more informative framework for assessing political support for social protection considers a country's 'social contract'. As Graham suggests, the extension of social protection 'ultimately requires the development of a politically sustainable social contract' (Graham 2002). Countries that have expanded publicly financed social protection in the last two decades, such as Brazil, have achieved this on the basis of a renewal of the social contract (Barrientos and Lloyd-Sherlock 2003).

To sum up, an understanding of the factors determining the dynamics of the social protection financing mix, including microeconomic and political economy perspectives, is essential to set current trends in an appropriate context. The next two sections focus on two key components of social protection financing: national governments' and international organisations' financing.

\section{Government financing of social protection}

National governments can support social protection through macroeconomic policy, public expenditure, tax policy, and regulation. Macroeconomic policies that ensure sustainable growth and fiscal stability are important in reducing vulnerability and in securing the resources needed for social protection. Public expenditures on basic and social services are in the main directed towards social protection. ${ }^{4}$ Tax policy helps ensure resources for social protection are adequate and can encourage households social protection expenditures through 'tax expenditures', i.e. tax exemptions applied to self-protection, saving, or insurance expenditures. Regulation covers a wide area: labour standards, employee benefits, financial regulation and access, and price regulation (utilities, foodstuff, merit goods, etc.). Key issues for discussion below are whether public expenditure on social protection is adequate, the constraints on tax financing, and the significance of distortionary effects from taxation and regulation.

Are governments spending enough on social protection? In theory, increases in public expenditure on social protection should stop at the point where the marginal benefits of that expenditure equal the marginal cost of raising public funds. In practice, it is a hard question to answer precisely. ${ }^{5}$ Taking a positive approach and examining current levels of expenditure across countries and regions suggests a number of stylised facts. Table 2 below shows public expenditure on social security across different regions of the world. There is considerable global, regional, and intra-regional variation, but broadly, there is a positive association existing between the level of economic development and public expenditure on social protection. Political economy factors, the nature of the social contract, and path dependence are also important, as the contrast between Europe and North America reveal. In low and middle income countries, donors play an important role in financing social protection expenditure and in setting the priorities for policy (Smith and Subbarao 2003).

What are the options facing developing countries wishing to raise their social protection spending from domestic revenue? Growth can generate additional revenues, but it is hard for low income countries to rely solely on this. Without growth, additional domestic revenues

\footnotetext{
${ }^{4}$ Public expenditure primarily directed at social protection includes expenditure on early childhood interventions, primary education, primary healthcare and public health, nutrition programmes, social services, social assistance, and disaster preparedness.

${ }^{5}$ Although in rough terms this is a 'no brainer'. Take an income transfer supporting schooling.

Psacharopulos estimates that the returns to education in Africa are 24, 18, and 11 percent respectively for primary, secondary, and tertiary education (Psacharopoulos 1994), while according to Warlters and Auriol the marginal costs of social funds for 38 countries in Sub-Saharan Africa average at 1.17 (it is necessary to collect US $\$ 1.17$ to make a US $\$ 1$ available for public expenditure) (Warlters and Auriol 2005). Any intervention with a rate of return at or over 17 percent is welfare enhancing.
} 
would require either increased tax revenues or deficit financing. Finance Ministers are reluctant to borrow in order to finance social protection, and in most plausible scenarios they would be ill-advised to take this route. There are harsh constraints on the capacity of developing countries to increase tax revenue collection. These constraints are associated with the structure of the economy, the rural subsistence economy and the informal sector are very difficult to tax, but also administrative capacity and political economy institutions. For the period 1995-97, tax revenue was 37.9\% of GDP among developed countries, but only $18.2 \%$ in a sample of developing countries (Tanzi and Zee 2000). There are also differences in the composition of the tax revenues. Developing countries rely to a larger extent on consumption and trade taxes, whereas developed countries are able to finance their social protection programmes with payroll taxes. See Figure 1 below for a comparison of the composition of tax revenue for developed and developing countries. Nevertheless, sustainable social protection institutions and programmes will need to be financed domestically at least in the medium term. The weight of evidence on this suggests that regressive, but efficient, taxation, coupled with progressive social protection expenditures could be more effective in supporting the extension of social protection in low income countries. Greater efficiency in the collection of existing taxes should have priority over efforts to extend the tax base.

Table 2. Public Expenditure on Social Security (as \% of GDP), 1999

\begin{tabular}{llllll}
\hline Region & $\begin{array}{l}\text { GNP } \\
\text { per } \\
\text { capita } \\
\mathbf{( 1 9 9 7}\end{array}$ & Pensions & Health & Other $^{1}$ & Total \\
& PPP) & & & & \\
& 1,868 & 1.4 & 1.7 & 1.2 & 4.3 \\
& 4,713 & 3.0 & 2.7 & 0.7 & 6.4 \\
\hline Africa & 13,040 & 12.1 & 6.3 & 6.4 & 24.8 \\
Asia & 6,695 & 2.1 & 2.8 & 3.9 & 8.8 \\
Europe & & & & & \\
Latin America and the & 28,346 & 7.1 & 7.5 & 2.0 & 16.6 \\
Caribbean & 15,461 & 4.9 & 5.6 & 5.6 & 16.1 \\
North America & & & & & \\
Oceania & &
\end{tabular}

${ }^{1}$ Includes work injury, sickness, family, housing, and other social assistance benefits in cash and kind

Source: World Labour Report 2000, ILO

The potentially distortionary effects of taxation need not be exaggerated. Concerns over whether this will exacerbate market distortions in developing countries need to be balanced with the fact that the excess burden of taxation is lower there (because it is broadly proportional to the level of tax revenues as a proportion of GDP), and markedly lower for income taxes. The perceived benefits from improved social protection, especially in the context of missing insurance markets, could generate conditions for a 'double dividend'. ${ }^{6}$

There is also scope for shifting expenditure from other areas towards social protection, but there are also practical obstacles to this shift. The timeframe for shifts in public expenditure is usually a long one, making this at best a medium-term objective. ${ }^{7}$ The political economy

\footnotetext{
${ }^{6}$ To the extent that increased taxation provides a corrective instrument for market imperfections that cause inefficiencies, the tax 'burden' could become a 'benefit', for example as a result of introducing a carbon tax (Atkinson 2003). The burning of hydrocarbon fuels is an important factor in global warming, and because the fuels contribute in proportion to their carbon content, a tax on their use in proportion to the amount of carbon burned would generate significant revenues, and a reduction in the use of environmentally harmful fuels (Clunie-Ross 1999).

${ }^{7} \mathrm{~A}$ shift of this nature could be facilitated by conditionality. The ILO has championed social budgeting as a tool for identifying potential gains from switching public expenditure, and to facilitate their implementation.
} 
literature on public sector reform suggests shifting public expenditure will be more difficult the greater the number of losers, and the more upfront the losses are. Among developed countries, raising public expenditure on social protection has been achieved by shifting the composition of tax revenues towards income, especially payroll taxes. Tax exemptions on foodstuff, school materials, agricultural tools, etc. are very common in developing countries. They tend to show large leakages to the non-poor while at the same time diminishing the tax base. In sum, the options for low and very low income countries wishing to expand social protection are very limited, they involve improving the efficiency of tax collection and shifting resources from less effective programme, and external finance is crucial.

Figure 1. Composition of tax revenue 1995-97 (\% of GDP)

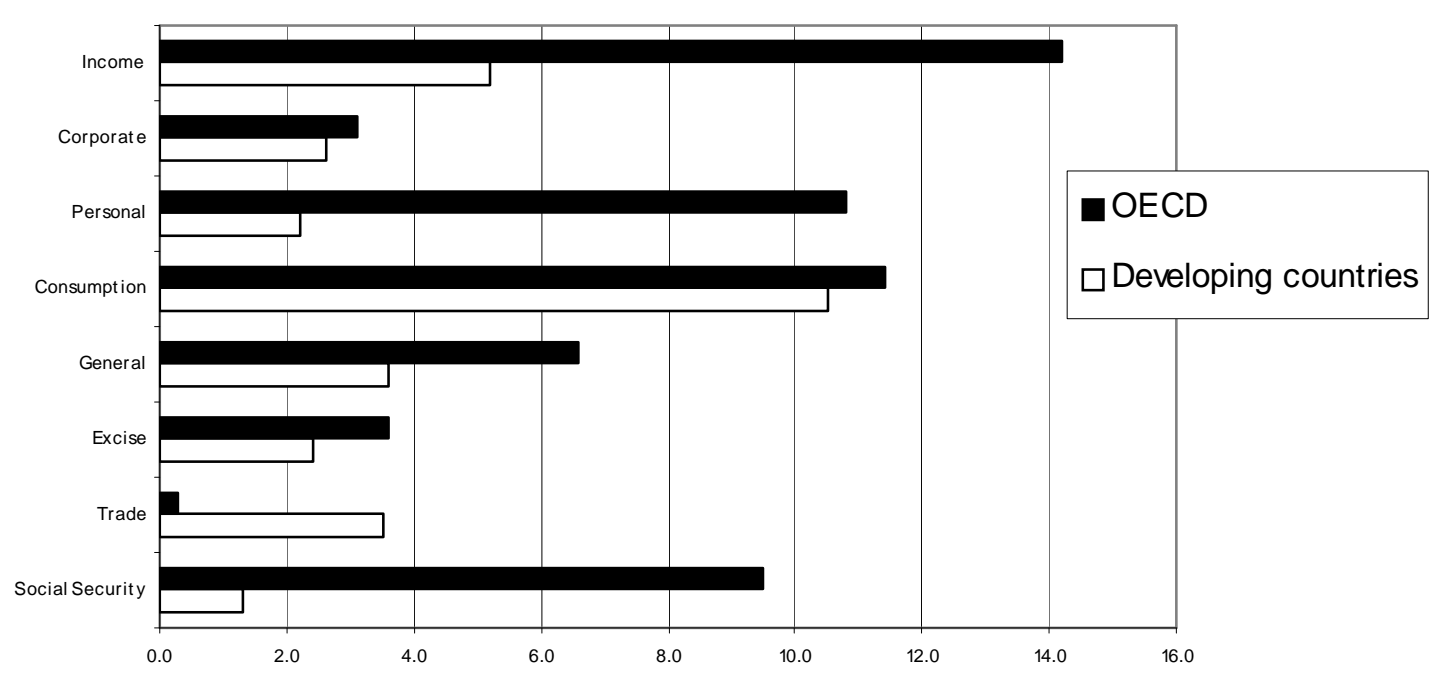

Source: Tanzi and Zee (2000).

\section{International organisations' financing of social protection}

The ILO has been largely responsible for the development of social protection instruments and institutions in the developing world (Usui 1994). The extension of the scope of social protection in the 1990s has meant that a number of other multilateral organizations that finance development programmes are also involved in social protection, e.g. the World Bank, UNDP, WHO, UNICEF, and others. In addition, regional organisations have developed and adopted social protection policy frameworks (IADB 2000; ADB 2001), or are in the process of doing so.

Are different forms of aid support more or less appropriate for social protection? It will be useful to focus on three main aid modalities: structural adjustment finance, provided by the IMF and World Bank to support a programme of policy reforms; general budget support, provided through the government budget, either as general support or targeted on specific sectors; and programme or project aid, providing finance earmarked for expenditure in pursuit of specific programmes or projects managed either by government/government agencies, or donors. In terms of financing social protection, there are advantages and disadvantages with the different aid instruments. They are summarised in Table 3 below, which pays special attention to conditionalities and earmarking as potential avenues for securing resources for social protection. 
The UK Government Department for International Development (DFID), which has taken a particular interest in social protection, has stated its intention to rely to a larger extent on budget support in the context of its poverty reduction objectives (DFID 2004). The expectation is that budget support will provide a partnership-based, predictable, and transparent mechanism for establishing a more productive policy dialogue, which supports institutional development, and especially government policy ownership and leadership in the recipient countries. For our purposes, the issue is how best budget support can help strengthen social protection. 
Table 3. Types of aid support and social protection

\begin{tabular}{|c|c|c|c|}
\hline Aid type & Social protection? & Conditionality? & Earmarking? \\
\hline $\begin{array}{l}\text { Structural } \\
\text { adjustment }\end{array}$ & $\begin{array}{l}\text { - Scope for supporting } \\
\text { social protection is low } \\
\text { - Social protection } \\
\text { introduced in the midst } \\
\text { of a crisis is unlikely to } \\
\text { be effective } \\
\text { - Polarisation is highest } \\
\text { during a crisis and } \\
\text { unlikely to result in a } \\
\text { new social contract }\end{array}$ & $\begin{array}{l}\text { - Targets macro-variables } \\
\text { - Policies which may be } \\
\text { effective in dealing with } \\
\text { crises may not be those } \\
\text { that best protect the poor } \\
\text { and vulnerable, and } \\
\text { conditionality may } \\
\text { involve a trade-off } \\
\text { - Need to ensure } \\
\text { adjustment lending does } \\
\text { not increase vulnerability } \\
\text { - Macro and fiscal } \\
\text { stabilisation rules may } \\
\text { contribute to reduce } \\
\text { vulnerability after the } \\
\text { crisis }\end{array}$ & - Not appropriate \\
\hline $\begin{array}{l}\text { Budget } \\
\text { support }\end{array}$ & $\begin{array}{l}\text { - Requires a } \\
\text { vulnerability } \\
\text { assessment } \\
\text { - Effective only if aid is a } \\
\text { significant share of } \\
\text { budget and there is } \\
\text { agreement on policy } \\
\text { priorities between } \\
\text { donors and } \\
\text { government } \\
\text { - Requires effective } \\
\text { institutions for policy } \\
\text { reform and } \\
\text { coordination across } \\
\text { ministries and } \\
\text { provinces } \\
\text { - Requires civil society } \\
\text { monitoring and } \\
\text { participation }\end{array}$ & $\begin{array}{l}\text { - Appropriate to ensuring } \\
\text { financing is additional to } \\
\text { current government } \\
\text { budgetary support } \\
\text { - Appropriate to ensure } \\
\text { coordinated policy } \\
\text { priority } \\
\text { - Appropriate to ensuring } \\
\text { the right instruments are } \\
\text { targeted on vulnerable } \\
\text { groups } \\
\text { But: } \\
\text { - Difficulty in identifying } \\
\text { indicators; indicators } \\
\text { deteriorate over time } \\
\text { - No clear link between } \\
\text { public expenditure and } \\
\text { outcomes }\end{array}$ & $\begin{array}{l}\text { - Effective only if } \\
\text { fungibility of } \\
\text { government } \\
\text { spending is } \\
\text { limited } \\
\text { - More effective in } \\
\text { sectoral budget } \\
\text { support, but at } \\
\text { this level the } \\
\text { boundaries with } \\
\text { conditionality } \\
\text { become blurred }\end{array}$ \\
\hline $\begin{array}{l}\text { Programme } \\
\text { or project } \\
\text { aid support }\end{array}$ & $\begin{array}{l}\text { - Vulnerability } \\
\text { Assessment a pre- } \\
\text { requisite } \\
\text { - More 'expensive' in } \\
\text { terms of political } \\
\text { support and } \\
\text { cooperation with } \\
\text { stakeholders } \\
\text { - Scope for 'co-funding' } \\
\text { with government and } \\
\text { other donors } \\
\text { - Requires investing in } \\
\text { technical capacity first } \\
\text { - Enables multi-country } \\
\text { and regional scope } \\
\text { - Can have large } \\
\text { demonstration effects }\end{array}$ & $\begin{array}{l}\text { - Appropriate to the use of } \\
\text { the funds }\end{array}$ & $\begin{array}{l}\text { - Appropriate and } \\
\text { effective } \\
\text { - Direct monitoring } \\
\text { of disbursement } \\
\text { and outcomes by } \\
\text { donors }\end{array}$ \\
\hline
\end{tabular}

Sources: DFID (mimeo); Collier and Dollar (2002); Cordella and Dell'Ariccia (2003 
The effectiveness of budget support aid is dependent on the quality of the partnership between donors and the national government. PRSs and vulnerability assessments enable a process of learning and understanding within government and civil society, and provide the basis for achieving a common understanding on poverty reduction goals, objectives, and targets.

Strengthening institutional capacity through budget support suggests a number of advantages with this aid modality in the context of social protection. Social protection will be more effective if it integrates interventions across sectors, and coordinates the efforts of a range of providers within the public, voluntary, and private sectors. Budget support can more easily identify these linkages, and support them effectively, especially compared with project aid. Budget support is also, on paper, more flexible in responding to changes in the pattern and significance of risks. Disbursement is more flexible.

The term structure of social protection is an important issue. Social protection interventions are most effective in the medium and long term. This is in stark contrast to the short term horizon favoured by donors, and the term structure of aid support, leaving infrastructure projects aside. The optimal length of time of a social protection programme may extend beyond the maximum period to which a donor may be willing to commit. For longer-term programmes, establishing partnerships with government and other donors will be important. Donors may be in a position to finance in full the start of a programme, but rely on the commitment of the government to gradually take over the financing of the programme after it has been successfully established. ${ }^{8}$

\section{Key issues and conclusions}

The objective of this section is to discuss some remaining issues and underscore others. The section ends with some conclusions:

What are the costs of raising domestic revenue for social protection? The public finance literature suggests there are costs to a market economy of raising revenue through taxation. Payroll taxes may reduce the incentives for work for marginal workers, and taxes on nonlabour income may reduce the incentives to save. ${ }^{9}$ This implies that in order to finance US\$1 for public expenditure, it may be necessary to raise US\$1.25, say, in revenue. The marginal cost of social funds may be greater than the amount needed for expenditure. ${ }^{10}$ At the same time, taxation may bring additional benefits to the economy, a social dividend, if for example carbon taxes reduce environmental damage in addition to raising revenue for public expenditure. There is an expectation that a social dividend might be available where taxes correct market imperfections. In this situation, the marginal cost of raising social funds may be less than the revenue collected. To the extent that social protection corrects market failures, in insurance, skills, and time preferences, it can be argued that the marginal cost of raising funds for social protection may be less than the actual spending. This implies that evaluating the returns of social protection programmes is important.

It was remarked above that the term structure of aid might be too short for the time framework involved in social protection programmes. It was also noted that external financing may provide the start-up funds needed, which are substantial. Persuading governments to

\footnotetext{
${ }^{8}$ The term structure for this contract may be an issue. The Global Social Trust programme, for example, envisages the provision of start-up capital and know-how for open-ended projects, with a gradual withdrawal of the trust after 10 years. There is also a political economy dimension to this. Once a programme becomes established, and evaluations show effectiveness and impacts, it becomes easier to ensure its political sustainability.

${ }^{9}$ In addition, there are costs associated with administration and enforcement of tax rules.

${ }^{10}$ The marginal cost of public funds is 'the multiplier to be applied to the direct resource cost in order to arrive at the socially relevant shadow price of resources to be used in the public sector' (Sadmo 1998).
} 
commit to gradually absorbing a social protection programme can be facilitated if it can be shown that the programme is effective, and political support for it is forthcoming. This involves, necessarily, a partnership with governments and a dialogue with civil society to engender the basis for a new social contract. ${ }^{11}$

To conclude, there is an emerging consensus that social protection provides a framework for addressing rising poverty and vulnerability. Financing an extension of social protection requires that attention is paid to the financing mix. Achieving an appropriate financing mix is essential to ensuring the resources required are available, but it is also important in strengthening the incentives for poverty and vulnerability reduction, and in reinforcing the legitimacy of social protection institutions and programmes. The task for developing countries is to raise the share of domestic revenue financing, in the context of increasing the volume of resources for social protection. There are important constraints to the capacity of national governments to achieve this, especially in low income countries. Constraints on revenueraising are strong, and switching expenditure is a protracted process. International organisations have an important role to play in supporting an enlargement of fiscal space for social protection. Their preference for short-term, sectoral, and infrastructure project lending, and the ineffectiveness of conditionality in structural adjustment and budget support, are important restrictions in their ability to support the extension of social protection. Strengthening social protection in developing countries may require sustained financial support and engagement with civil society, around integrated policy interventions.

\footnotetext{
${ }^{11}$ This is in line with the findings of Assessing Aid on what makes aid successful (World Bank 1998).
} 


\section{References}

ADB (2001) Social Protection Strategy. Manila, Philippines: Asian Development Bank.

ADB (2002) Social Protection Strategy. Manila, Philippines: Asian Development Bank.

Atkinson, A.B. (2003) Innovative sources for devloping finance - Global public economics. Oxford, UK: Oxford University Press.

Auriol, E. \& Warlters, M. (2002) Taxation base in developing countries. Toulouse, France: ARQADE.

Barrientos, A. (2004) Regulation and Social Protection. In Cook, P., Kirkpatrick, C., Minogue, M. \& Parker, D. (Eds.) Leading Issues in Competition, Regulaton and Development. London, UK: Edward Elgar.

Barrientos, A. (2006) Social Assistance in Developing Countries Database. Brighton, UK: Institute of Development Studies.

Barrientos, A. and Holmes R. (2006) Social Assistance in Developing Countries Database. Brighton: Institute of Development Studies.

Barrientos, A. and Lloyd-Sherlock, P. (2003) Non-contributory pensions and poverty prevention. A comparative study of Brazil and South Africa. Manchester, UK: University of Manchester.

Braun, M. \& di Gresia, L. (2003) Towards effective social insurance in Latin America: The Importance of countercyclical fiscal policy. Washington D.C.: Inter-American Development Bank.

CARICOM-Secretariat (2002) Framework for Stabilising and Transforming Caribbean Economies. Press Release. Castries, St. Lucia: CARICOM Secretariat.

Clunie-Ross, A. (1999) Resources on Global Development. New York, NY: United Nations.

Coady, D. (2003) Alleviating structural poverty in developing countries: The approach of Progresa in Mexico. Washington D.C.: International Food Policy Research Institute.

Collier, P. and Dollar D. (2002) Aid Allocation and Poverty Reduction. European Economic Review, vol. 46, pp. 1475-1500.

Commission-for-Africa (2005) Our Common Interest. London, UK: Commission for Africa.

Cordella, T. and Dell'Ariccia G. (2003) Budget Support vs Project Aid. IMF Working Papers WP/03/88, Washington DC: IMF.

DFID (2004) Poverty Reduction Budget Support. London: Department for International Development, U.K. Government.

Ehrlich, I. \& Becker, G.S. (1972) Market Insurance, Self-insurance and Self-protection. Journal of Political Economy, 80.

Gelbach, J.B. \& Pritchett, L. (1995) Does more for the poor mean less for the poor? The politics of targeting. Policy Research Working Papers. Washington D.C.: World Bank.

Gill, I.S. \& Ilahi, N. (2002) Economic insecurity, economic behaviour and social policy. Washington D.C.: World Bank.

Graham, C. (2002) Public Attitudes Matter: A Conceptual Frame for Accounting for Political Economy in Safety Nets and Social Assistance Policies. World Bank Social Protection DIscussion Paper. Washington D.C.: World Bank. 
Gruber, J. (1997) The Incidence of Payroll Taxation: Evidence from Chile. Journal of Labour Economics, 15, S72-S101.

Hicks, N. \& Woodon, Q. (2001) Protección social para los pobres en América Latina. Revista de la Cepal, 73, 95-116.

Holzmann, R., Sherbourne-Benz, L. \& Tesliuc, E. (2003) Social risk management: The World Bank's approach to social protection in a globalizing world. Washington D.C.: Human Development Network, World Bank.

IADB (2000) Social Protection for Equity and Growth. Washington D.C.: Inter-American Development Bank.

ILO (2000), World Labour Report 2000, Geneva: International Labour Office.

ILO (2001) Social Security: Issues, challenges and prospects. Report VI. Geneva, Switzerland: International Labour Office.

Lustigf, N. (2000) Crises and the Poor: Socially Responsible Macroeconomics, Sustainable Development Department. Technical Paper Series. Washington D.C.: Inter-American Development Bank.

Morley, S. \& Coady, D. (2003) From social assistance to social development: Targeted education subsidies in developing countries. Washington D.C.: Centre for Global Development and International Food Policy Research Institute.

Psacharopoulos, G. (1994) Returns to investment in education: a global update, Washington D.C.: World Bank.

Sadmo, A. (1998) Redistribution and the marginal cost of public funds. Journal of Public Economics, 70, 365-382.

Smith, W.J. \& Subbarao, K. (2003) What role for safety net transfers in very low income countries? Social Protection Discussion Paper. Washington D.C.: World Bank.

Suryhadi, A. \& Subbarao, K. (2001) The chronic poor, the transient poor, and the vulnerable in Indonesia before and after the crisis. Working Paper. Jakarta, Indonesia: SMERU.

Tanzi, V. \& Zee, H.H. (2000) Tax policy for emerging markets: developing countries. IMF Working Papers. Washington D.C.: International Monetary Fund.

Usui, C. (1994) Welfare state development in a world system context: event history analysis of first social insurance legislation among 60 countries, 1880-1960. In Janoski, T. \& Hicks, A.M. (Eds.) The Comparative Political Economy of the Welfare State. Cambridge, UK: Cambridge University Press. 254-277.

Warlters, M. \& Auriol, E. (2005) The Marginal Cost of Public Funds in Africa. Policy Research Working Paper. Washington D.C.: World Bank.

WHO (2003) The World Health Report. Geneva, Switzerland: World Health Organization.

World Bank (1998) Assessing Aid: What Works, What Doesn't and Why. Oxford, UK: Oxford University Press. 


\section{Executive Director}

Professor Tony Addison

Research Director

Professor Michael Woolcock

\section{Associate Director}

Professor David Hulme

\section{Contact:}

Brooks World Poverty Institute

The University of Manchester

Humanities Bridgeford Street

\section{Building}

Oxford Road

Manchester

M13 9PL

United Kingdom

Email: bwpi@manchester.ac.uk
The Brooks World Poverty Institute (BWPI) creates and shares knowledge to help end global poverty.

BWPI is multidisciplinary, researching poverty in both the rich and poor worlds.

Our aim is to better understand why people are poor, what keeps them trapped in poverty and how they can be helped drawing upon the very best international practice in research and policy making.

The Brooks World Poverty Institute is chaired by Nobel Laureate, Professor Joseph E. Stiglitz. 